
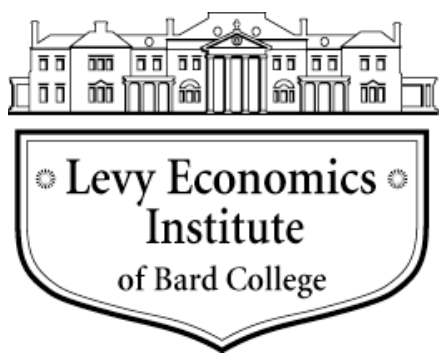

Working Paper No. 842

\title{
Making the Euro Viable: The Euro Treasury Plan*
}

by

\author{
Jörg Bibow \\ Levy Economics Institute of Bard College
}

July 2015

\begin{abstract}
* This paper is the winning paper in the category "Reforming European economic governance," presented at the Progressive Economy Annual Forum, 3 June 2015, in Brussels, Belgium. The Progressive Economy initiative was launched in 2012 by the Group of the Progressive Alliance of Socialists \& Democrats in the European Parliament.
\end{abstract}

The Levy Economics Institute Working Paper Collection presents research in progress by Levy Institute scholars and conference participants. The purpose of the series is to disseminate ideas to and elicit comments from academics and professionals.

Levy Economics Institute of Bard College, founded in 1986, is a nonprofit, nonpartisan, independently funded research organization devoted to public service. Through scholarship and economic research it generates viable, effective public policy responses to important economic problems that profoundly affect the quality of life in the United States and abroad.

Levy Economics Institute P.O. Box 5000

Annandale-on-Hudson, NY 12504-5000

http://www.levyinstitute.org

Copyright (C) Levy Economics Institute 2015 All rights reserved 


\begin{abstract}
The euro crisis remains unresolved and the euro currency union incomplete and extraordinarily vulnerable. The euro regime's essential flaw and ultimate source of vulnerability is the decoupling of central bank and treasury institutions in the euro currency union. We propose a "Euro Treasury" scheme to properly fix the regime and resolve the euro crisis. This scheme would establish a rudimentary fiscal union that is not a transfer union. The core idea is to create a Euro Treasury as a vehicle to pool future eurozone public investment spending and to have it funded by proper eurozone treasury securities. The Euro Treasury could fulfill a number of additional purposes while operating mainly on the basis of a strict rule. The plan would also provide a much-needed fiscal boost to recovery and foster a more benign intra-area rebalancing.
\end{abstract}

Keywords: Economic and Monetary Union; Euro Crisis; Euro Treasury; Fiscal Union; Public Investment

JEL Classifications: E32, E62, E63, H62, H63 


\section{INTRODUCTION}

The euro crisis has exposed existential flaws in the euro regime. Preceding the crisis, intra-area divergences and the corresponding buildup of grave imbalances remained unchecked. As those imbalances eventually imploded, member states were found extremely vulnerable to systemic banking problems and abruptly deteriorating public finances. Lacking a (federal) treasury partner, the European Central Bank (ECB) battled to stem area-wide contagion while becoming exposed to legal challenges of its quasi-fiscal policies. Today, most member states continue struggling under stagnation, high unemployment, and adverse debt dynamics, while questions remain over the effectiveness of the ECB's recently launched "quantitative easing" (QE) initiative. Vulnerable to global developments, on which it is unduly reliant as mirrored in a soaring current account surplus, the euro currency union remains stuck in a crisis of its own making, with little hope for emerging from it with any degree of vigor under its flawed and dysfunctional policy regime.

Especially investment spending, both private and public, is stuck at a deeply depressed level. Laboring under the budgetary constraints imposed by the euro regime, the Stability and Growth Pact (SGP) and Fiscal Compact, governments across the eurozone have cut public investment spending to an extraordinarily low level (around two percent of GDP). The jointlyundertaken austerity frenzy has proved counterproductive from a cyclical perspective, as well as socially devastating. The situation is also highly detrimental from a long-term growth perspective (see Ball 1997; DeLong and Summers 2012; Blanchard and Leigh 2013; Eyraud and Weber 2013; and Perotti 2013, for instance). Essentially, governments are not only recklessly spoiling the economic fortunes of current generations, but also reneging on the economic possibilities for our grandchildren.

The proposal put forward here features an area-wide boost to public investment that amounts to a joint recovery program. In that regard it is not the first and only of its kind. ${ }^{1}$ What is novel about the "Euro Treasury plan" is the way in which it joins the spending and financing sides of a recovery program that would, at the same time, also fill the void in the current euro regime and heal its essential flaw and ultimate source of vulnerability: the decoupling of central bank and treasury institutions.

\footnotetext{
${ }^{1}$ See Deutscher Gewerkschaftsbund (2012), Varoufakis et al. (2013), and ECLM/IMK/OFCE (2014), for instance.
} 
The euro is lacking a safe footing for as long as the ECB is missing a (federal) treasury partner-establishing that vital treasury-central bank axis that stands at the center of power in sovereign states (Godley 1992; Goodhart 1992, 1998). The current regime leaves all players vulnerable. Lacking a central bank partner, the national treasuries are subject to default and, hence, runs. Lacking a Euro Treasury partner and Euro Treasury debt, the ECB is subject to legal challenges of its quasi-fiscal policies as applied to national debts. The Euro Treasury plan kills two, if not more, birds with one stone, while going a long way toward accommodating some key German reservations as well.

\section{EURO TREASURY: A VEHICLE FOR JOINT FUNDING OF PUBLIC INVESTMENT}

At the heart of the Euro Treasury scheme proposed here is a simple and straightforward idea. The idea is to create a Euro Treasury as a vehicle to pool future eurozone public investment spending and have it funded by proper eurozone treasury securities. Member state governments would agree on the initial volume of common area-wide public investment spending and on the annual growth rate of public investment thereafter. Beyond that, the Euro Treasury operates on auto-pilot.

Take the famous Maastricht parameters as an example, a 3-budget deficit ratio and a 60percent public debt ratio. So assume agreement on 3 percent of GDP as the initial volume of public investment, annually increased at a 5-percent rate thereafter. If the implicit Maastricht assumption of five percent annual nominal GDP growth were to hold, the eurozone would henceforth see steady investment in its common infrastructure while the common Euro Treasury debt stock funding it would converge to a steady-state level of 60 percent of GDP by the end of the century. In fact, the biggest part of the adjustment would be completed within 30 to 40 years. In other words, within one generation, Europeans would share both a common infrastructure stock and the public debt that has funded it.

This is not simply another "euro bonds" proposal, though. ${ }^{2}$ In particular, there is no debt mutualization of existing national debts involved here. Member states alone would remain responsible for their respective national public debt. The no-bailout clause would stay in place. The Euro Treasury scheme is purely forward-looking, with new common debt funding new

\footnotetext{
${ }^{2}$ See Brunnermeier et al. (2011), Claessens et al. (2012), Delpla and Weizsäcker (2010), and Hellwig and Philippon (2011), for instance.
} 
public investment as the basis of the region's - much alluded to but currently grimly neglected-common destiny and future.

The Euro Treasury will not directly undertake the investment spending itself. Instead, it will give investment grants to member state governments exactly in line with member states' GDP shares (say, five-year averages) or, alternatively, based on the ECB's capital key (which gives equal weight to GDP and population shares). The point is that the same shares used to calculate member states' investment grants are also used to calculate their interest payment obligations. The Euro Treasury will apply its power to tax and raise revenue to meet the interest service on the common debt exactly in proportion to member states' GDP. With both grants and tax contributions based on member states' GDP shares, redistribution is excluded by design: the Euro Treasury is specifically designed not to be a transfer union. This design rules out one key political obstacle for fiscal union. The Euro Treasury is separate from and runs parallel to the EU budget, which remains the sole instrument of any intra-regional redistribution.

In line with the EU's subsidiarity principle, the Euro Treasury's power to tax is strictly limited to obtaining revenues to service the interest on the debt and keep the debt ratio stable at its target level. On the revenue side of the plan, special tax provisions are designed to generate revenue earmarked for servicing the debt. This may be bolstered by a deposit of international reserves equivalent to member states' yearly tax obligations. Legally, eurozone member states could follow the example of the Fiscal Compact and enter into an intergovernmental treaty outside the EU framework together with measures to be introduced in national legislation. The fact that there will be no discretion in fiscal decision-making beyond agreeing the initial parameters of the scheme take care of the other main political obstacle to fiscal union in Europe. The Euro Treasury functions on the basis of a strict rule. There is a strong political case for organizing public investment spending on a strict rule when managed and funded from the center for as long as there is no full-fledged parliamentary democracy in place in the eurozone.

\section{MEMBER STATES MUST ABIDE BY THE CURRENT FISCAL REGIME}

Member states will still be required to abide by all the rules of the current euro regime, including recent reforms, but applied to current public expenditures only (see Blanchard and Giavazzi 2004) — as national public capital expenditures now form a separate capital budget funded through common Euro Treasury securities. This makes a vital difference. 
The euro crisis is widely, if wrongly, blamed on fiscal profligacy and a supposed lack of compliance with the rules of the SGP. The point is that attempting to unconditionally balance the budget and reduce national public debts to very low levels without establishing the crucial treasury-central bank axis and organizing deficit spending at the center is not a workable regime solution. The current regime envisions member states running (near-) balanced public budgets forever, which would see public debt ratios decline toward (near) zero in the long run. This is a truly impossible endeavor. Not only would it starve the financial system of safe assets. It also sets up a lop-sided regime that shifts all debt onto weaker (private) shoulders, thereby creating perfectly avoidable financial and economic fragilities. Debt - and in fact growing public debtis a very natural concomitant phenomenon of economic growth. The euro regime is lacking a central fiscal institution with the power to spend, tax, and issue debt. This void is the key source of its vulnerability and ill-performance.

Especially following a financial crisis, marked by excessive leverage, the private sector will seek to run a financial surplus. Only when the recovery has turned into a new boom can we expect the private sector to reach a balanced financial position (or even a temporary deficit). Given a structural financial surplus for the private sector over the cycle, the public sector can only realistically balance its books structurally if the country (or currency union) runs perpetual external surpluses. This amounts to the German model, which provided the root cause behind the unresolved euro crisis. Replicating the German model for the eurozone as a whole will persistently depress the domestic economy and provoke global tensions - as it already does. The eurozone's soaring current account surplus is in stark conflict with G-20 commitments to global rebalancing. The German model is the wrong model for the eurozone (Bibow 2001, 2013a, b). 
Figure 1 Central and National Debt Ratios: Convergence to Steady State

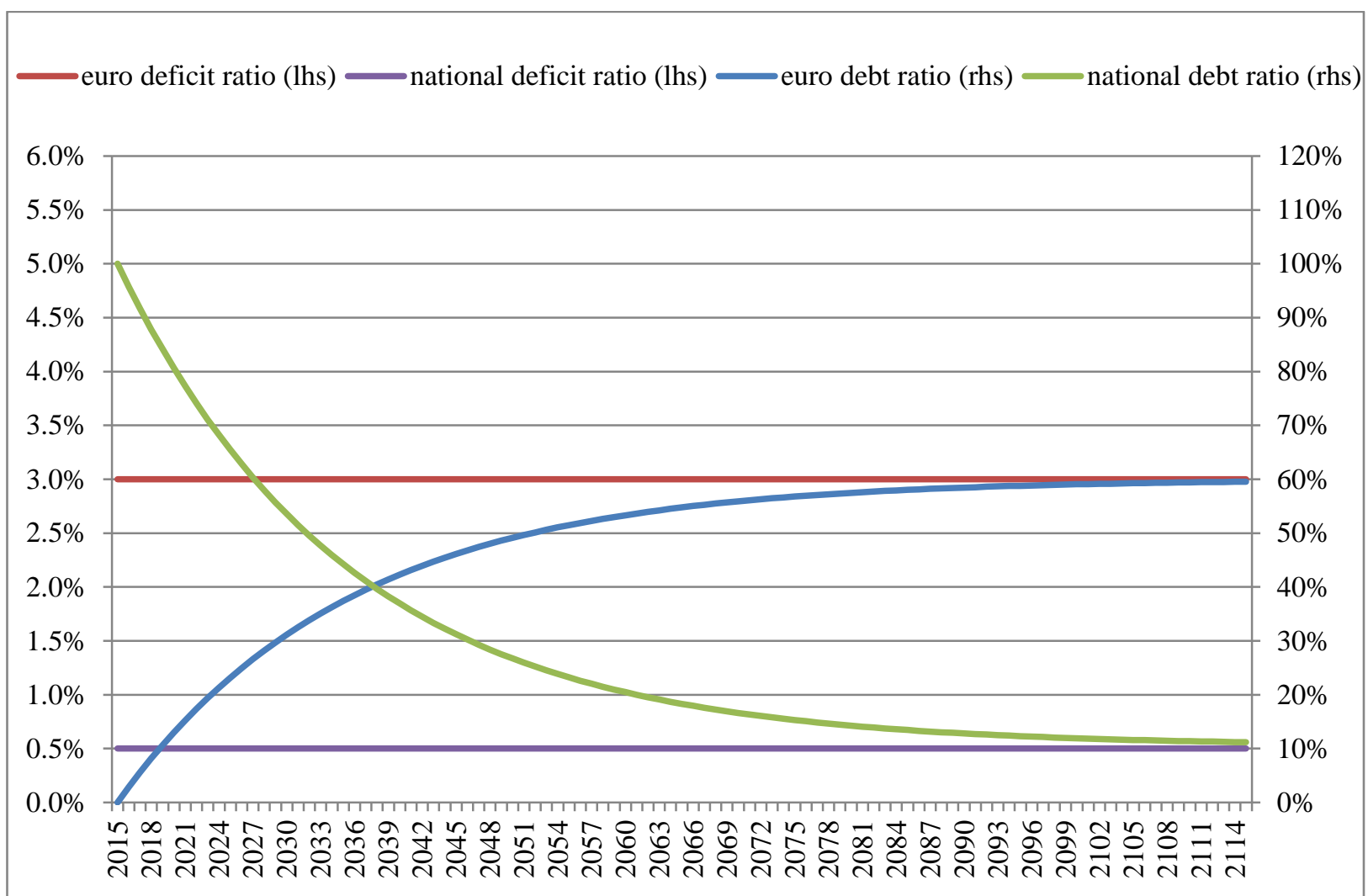

As to the evolution of national public debts under the Euro Treasury plan, steady deficit spending on public investment funded at the center that is the basis of Europe's common future will finally allow and enable national treasuries to (nearly) balance their structural current budgets. Within one generation, there will be little national public debt left to worry about (see Figure 1). Member states would see the interest burden on their old national debt shrink in line with the declining national debt ratio while their interest burden of the new joint Euro Treasury debt will gradually build up. In general, member states will experience a decline in their overall interest burden as cheaper debts replace more expensive debts over time. While mimicking the original Maastricht criteria of fiscal rectitude and stability at the union level, the overall outcome would also resemble the situation in another-functioning-currency union during normal times: the United States.

In essence, perpetual deficit spending from the center organized through a Euro Treasury issuing proper Euro Treasury bonds meets the systemic requirements of the region, while also providing the safe assets the financial system needs to function. The Euro Treasury is the 
missing element in the current euro regime: it can actually make that very regime work, a regime which is inherently flawed and unworkable without it.

Adding that missing element to the current regime will also make compliance and enforcement a lot easier. While the SGP features a seemingly big "stick" of onerous sanctions that may however be unenforceable in practice, the Euro Treasury handles the compliance issue far more convincingly: the Euro Treasury will automatically withhold investment grants in case of noncompliance with the balanced (structural) budget rule as applied to current expenditures —and by the full amount by which the target is missed. Member states thus have a very strong incentive not to miss out on the investment grant "carrot." Any target miss — and its public finance costs in terms of missed investment grants - will surely reverberate with the public media and financial markets.

\section{A MINIMALISTIC FISCAL UNION THAT SAFEGUARDS EUROPE'S INFRASTRUCTURE AND COMMON FUTURE}

Effectively, the Euro Treasury plan would create a minimalistic but functional fiscal union that follows the subsidiarity principle and accommodates some key German reservations. In particular, the proposal does not constitute a transfer union; it requires that the member states abide by all the rules of the current fiscal regime (as applied to current, but not capital, spending), and it foresees that the Euro Treasury operates on a fixed rule rather than by discretion. The fixed rule for its operation is known as the "golden rule of public finance" (Musgrave 1939, 1959), which was anchored in Germany's constitution until it was replaced by the "debt brake" in 2009 (Deutsche Bundesbank 2012). The latter essentially amounts to a balanced-budget rule, while the former acknowledges that public investment should be debt financed.

By steadying public investment at an adequate level, the Euro Treasury would provide a basic ingredient for turning the euro into an engine for joint prosperity rather than joint impoverishment. Steady and healthy public investment will safeguard the eurozone's infrastructure and common future, and it will also help stabilize economic activity and investment spending generally. What distinguishes the Euro Treasury from alternative proposals emphasizing public investment as a prerequisite for recovery and growth is that the Euro Treasury plan features a straightforward way of funding Europe's infrastructure; on an ongoing basis. The Euro Treasury thereby epitomizes that both sides of the balance sheet matter: 
issuance of common Euro Treasury bonds serves to fund the infrastructure upon which Europe's future will rest. The current austerity crusade denies the conventional wisdom of the "golden rule of public finance" and impoverishes Europe. The Euro Treasury turns that "golden rule" of sound public finances into the anchor of the European integration process.

Other existing EU institutions or instruments may complement but not substitute for a proper Euro Treasury issuing proper Euro Treasury securities. For instance, there may be a role for the European Investment Bank (EIB), the European Investment Fund, the Commission's socalled "Project Bonds," and private-public partnerships. But while the EIB's expertise can be called upon in selecting and designing particular projects, its balance sheet cannot be levered up to an extent that would make a Euro Treasury superfluous. The EIB's capital subscriptions are backed by the EU (rather than the eurozone, adding a further complication) member states' national treasuries, each of which is in a vulnerable position due to its divorce from a fully empowered national central bank. The eurozone will not be able to overcome its vulnerability to crisis and jointly invest in its future, thereby anchoring the European integration process in a safe and sound way, without establishing a strong treasury-central bank axis at its center.

\section{CONSIDERING SOME ADDITIONAL POTENTIAL FUNCTIONS OF THE EURO TREASURY}

\section{Eurozone Stabilization Policy and Automatic Stabilizers}

The experience of macroeconomic performance under the euro regime has revealed insufficient fiscal stabilization capacity both following the normal cyclical downturn in the early 2000s and much more so in the context of severe crisis since 2008. The SGP triggered pro-cyclical consolidation in the 2000s, which hindered prompt recovery (Bibow 2006a; Hein and Truger 2007). Worse, under market and policy pressures, member states have pursued counterproductively brutal austerity policies since 2010, which trapped the eurozone economy in prolonged recession (Bibow 2013b; Darvas et al. 2013). The common presumption of fiscal profligacy and supposed lack of ambition in good years is missing the point. Ever since Europe embarked on the euro project, the good years were shallow and few. The current euro regime is flawed and dysfunctional. In particular, fiscal policy has notoriously failed to play any constructive part in macroeconomic stabilization.

That said, it is true that, by itself, the Euro Treasury's essential function in managing and funding public investment spending in the eurozone does not actually constitute a stabilization 
policy as it is commonly understood. Based on a strict rule, public investment spending will not be counter-cyclical but merely steady; (German-style) "stability policy" rather than proper stabilization policy. Indirectly, however, the Euro Treasury nevertheless contributes to the public finance function of stabilization in significant ways. Most importantly, by requiring and enabling the decline of national public debt ratios to very low levels in abidance with the rule of balancing structural current budgets at the national level, member states will restore their fiscal space, allowing the automatic stabilizers to function freely. The Euro Treasury leaves the main fiscal stabilization responsibility at the national budget level, where large built-in automatic stabilizers exist. It foresees no principle change in this regard. The point is that seemingly large automatic stabilizers are of no use if they get quickly shut off when they are needed the most. Continuous deficit spending at the center and the commensurate buildup of federal debt (as the system's safe asset) does the trick. National automatic stabilizers would thereby regain the necessary breathing room to actually do their job. (Persistent large current account surpluses are no alternative.)

Of course, the existence of a central Euro Treasury also establishes the institutional capability for a stronger common response to common (symmetric) shocks. Even the original Maastricht regime featured the escape clause that breeching the 3-percent deficit limit would not constitute any "excessive deficit" in case of severe recessions (declines in GDP by 2 percent or more). The strict ("golden") rule for debt-financing steady public investment spending could be easily augmented to cover this case. In severe recessions, the Euro Treasury could (automatically) extend additional all-purpose grants to member states (on the basis of their GDP shares) that support member states' budgets. This would provide extra breathing room for quasiautomatic stabilization put into effect in a decentralized way. As a result, there would be a temporarily faster rise in Euro Treasury issuance and a correspondingly milder rise in national debt issuance. This outcome is critically important because the Euro Treasury is paired up with a central bank partner, the ECB, while the national treasuries are not (and hence inherently vulnerable). Once recovery is established, the tax for servicing Euro Treasury debt could be temporarily raised so as to assure re-convergence to the target debt ratio for euro treasury debt within a certain time period. 


\section{The Euro Treasury as a Backstop for the "Banking Union" and Safe Asset Provider}

The Euro Treasury Plan establishes the missing treasury-central bank axis at the eurozone's center, which is also vital when it comes to anchoring the stability of the financial system. The vulnerability of the original euro regime has become most obvious in this very area. In this regard, it is conventional wisdom today that Europe's monetary union is incomplete without "banking union.” Indeed, a long time ago, Europe set out to establish a common market, including in banking, but forgot to pair it with a common policy. Repair of this defect is ongoing. Various initiatives are under way today to coordinate, harmonize, or properly integrate national and EU policies in the area of financial stability policy.

The most important objective of the banking union is to break the infamous "banksovereign doom loop." The "doom loop" arises as the two parties are closely intertwined in terms of their liquidity and solvency status. Banks typically hold debts issued by their sovereign as liquid and safe investments and government debt securities also play a critical role as collateral and the financial system's safe asset more generally. A sovereign downgrade can therefore have a profound impact on banks in particular. The sovereign, in turn, not only relies on banks as lenders/investors, but is also their ultimate fiscal backstop when banks need to be recapitalized to avoid a financial meltdown. Banking problems can have severe budgetary consequences. Not being in a position to prevent a financial meltdown can be even more costly though.

It is widely held that banking supervision has been set on a sound footing through the "Single Supervisory Mechanism" (SSM) that went into effect in November 2014. The SSM entrusts the ECB as the principal supervisor for all banks in eurozone countries. The ECB has direct supervisory powers over (systemically) "significant" banks, but may also assert its supervisory authority over "less significant" ones, the day-to-day supervision of which was otherwise left to the national authorities. In any case, the ECB, the national supervisory authorities, and the European Banking Authority, are now supposed to act as one common supervisory system, with the ECB responsible for the overall effectiveness of the SSM. The (ongoing) implementation process of the latest bank capital adequacy standards (and related rules; "Basel III"; see BCBS 2011) by means of the Capital Requirements Regulation and Directive (“CRD IV/CRR") features a greater degree of harmonization of rules and leaves the member states correspondingly less leeway in national transposition than used to be the case in 
the past (Howarth and Quaglia 2013). The SSM will hopefully ensure more harmonized and common compliance as well. These are welcome developments.

Other critical elements in the banking-union project remain largely unfinished business. Regarding deposit insurance, only the level of deposit guarantee was harmonized (at up to $€ 100,000)$ and a uniform ex-ante target level for the deposit guarantee scheme's financing agreed (of at least 0.8 percent of the amount of the covered deposits, raised through a levy on member banks). Regarding resolution of troubled banks Europe chose to explore unchartered waters. The EU has agreed to "bail in" rather than "bail out" creditors in the future: the "Bank Restructuring and Resolution Directive" enshrines the bail-in principle EU-wide. Apart from containing any potential future recourse to taxpayer money overall, the other foremost concern was to limit any potential risk-sharing among member states.

Protecting tax payers from incompetence and fraud committed by rich and reckless bankers is a very laudable idea. Arguably, however, the arrangements foreseen in the new bank restructuring and resolution regime have left Europe's currency union in a very precarious state. The foreseen solvency backstops are insufficient and remain largely national. In particular, any recourse to the Single Resolution Fund (SRF) not only requires prior bail-in of creditors, but is also capped (at five percent of the failed institution's liabilities). The SRF will be constituted from contributions by the banks from participating member states, with an ultimate target level of $€ 55$ billion to be accumulated over eight years. The SRF can borrow additional resources from the markets and impose ex-post levies on the banks for recuperation. Initially comprising national compartments, the SRF will then be progressively mutualized over the eight-year horizon. In short, the extent of future risk-sharing will be rather limited in amount and apply to banks' contributions rather than taxpayer money in the first instance. Risk-sharing of taxpayer money will only arise as a last resort through the European Stability Mechanism (ESM). However, the last-resort fiscal backstop ESM is only foreseen to directly inject equity into banks - the amount being capped at $€ 60$ billion — if providing a loan to the national government would push its debt ratio to unsustainable levels. Investor bail-in, the $€ 55$ billion SRF, and $€ 60$ billion from the ESM for any particular country, make up the envisioned euro area defense against future financial crises. It is a grand illusion that the banking union in its current or foreseen shape may have successfully put the bank-sovereign (doom) loop to rest (Avgouleas and Goodhart 2014). 
At times of emergency, there may be severe limits to the practicability of stemming contagion by bailing in creditors (including depositors). The public authorities must be in a position of strength to be able to effectively counter systemic events. The ECB has the liquidity firepower to stem contagion, but lacks the equivalent of the US Treasury's deep pockets to pair up with. If banking union is a required complement to monetary union, so is fiscal union, featuring a sufficiently strong common fiscal backstop at the center. Moreover, with common supervision in place today, it is starkly inconsistent that any potential fiscal burden of financial crises should still principally land on national treasury shoulders; a case of "taxation without representation" (Ubide 2013). Coupling the quick pockets of the ECB with the deep pockets of the Euro Treasury would provide a strong bulwark against the threat of a financial meltdown. As the necessary ultimate backstop for the financial system, the Euro Treasury would replace the unwieldy ESM backed by national contributions, that is, national treasuries that are individually vulnerable since they are divorced from their national central banks. The Euro Treasury will be funded by a debt instrument designed to equal US Treasury securities - a debt instrument the ECB can purchase for monetary policy and financial stability purposes without facing legal challenges.

A Euro Treasury partner is therefore of great benefit to the ECB, both in its capacity as monetary policymaker and key authority in financial stability policy. With the establishment of a Euro Treasury partner, the ECB would henceforth operate in Euro Treasury securities only but never touch national sovereign debt again. With the Euro Treasury in place national public debt ratios will be required and enabled to decline to low and safe levels. Accompanied by banking regulations that effectively prevent the concentration of national sovereign debt instruments on bank balance sheets (Goodhart 2007), the Euro Treasury will thereby both cut through the "bank-sovereign (doom) loop" and make the "no-bailout clause" workable at the same time. Europe's common market yearns for a common, safe asset that can serve as the basis for establishing a common term structure of (risk-free) interest rates. This is an essential precondition for a truly single ECB monetary policy and proper financial market integration. Currently, private creditors across the eurozone are facing diverging borrowing costs and credit spreads based on their nationality as private credit risks continue to be priced off their respective national benchmark. This situation starkly conflicts with the whole purpose of both the common market and the common currency. The Euro Treasury plan would overcome this fundamental challenge. In contrast to "euro bonds" proposals, there is no purchasing, repackaging, or 
mutualization of any existing national debts involved, though. The Euro Treasury plan is purely forward-looking: Euro Treasury securities fund future public investment spending. By acting as the ultimate fiscal backstop to Europe's banking union, the Euro Treasury can, in principle, provide a flexible and reliable emergency funding source — the "big bazooka" that will hopefully never be called upon.

Suffice to mention that while the Euro Treasury is generally operable on the basis of a strict rule, in the area of crisis management and resolution, some discretion would be inevitable. This is no different from the current situation regarding the ESM though, only that the Euro Treasury rests on a much sounder funding basis and restores the treasury-central bank axis of power at the center.

\section{Mutual Insurance and Temporary Transfers}

As argued above, the Euro Treasury would be an important stabilizing force in the case of common or symmetric shocks like the eurozone business cycle, both through steadying public investment spending and through restoring national fiscal space and allowing the free working of the automatic stabilizers at the national level. Potentially, the Euro Treasury could also play a supplementary role in dealing with idiosyncratic or asymmetric shocks-shocks that affect currency union members differently. Asymmetric shocks have been the main focus of mainstream thought regarding currency unions ("optimum currency area"; Mundell 1961). Yet it is important to clearly distinguish two varieties of asymmetric shocks presenting very different policy challenges. Asymmetric shocks can be either truly exogenous, leaving member states with opposing policy and/or adjustment requirements despite fully abiding by the rules of the currency union policy regime. Or they can arise endogenously from the nonconforming behavior of members and the (mal-) functioning of the policy regime itself.

Only in the case of properly exogenous asymmetric shocks does mutual insurance recommend itself. Mutual insurance is different from redistribution policy (see European Council 2012 and Tommaso Padoa-Schioppa Group 2012). The latter features permanent transfers that are meant to reduce differences in income levels among member states. In the EU, cross-member redistribution policy is mainly handled through the EU budget; a tightly limited "transfer union," the extent of which is regularly renegotiated. By contrast, a mutual insurance scheme featuring temporary fiscal transfers may be specifically designed to meet the stabilization purpose only, rather than redistribution. This is achieved by making fiscal transfers 
a function of the rate of change of economic activity rather than the level (Goodhart and Smith 1993). Transfers are triggered when the rate of change of economic activity in any particular member state(s) deviates from the union average by a certain margin. Transfers are temporary by design. They automatically end in case of re-convergence of the rate of change to the average. If it is assumed that asymmetric shocks are randomly distributed, then transfers will tend to balance out for countries over time and no permanent transfers arise.

Such a mutual insurance scheme may be run on the basis of a rainy day fund, but it seems far more straightforward to use the Euro Treasury as the conduit through which member states make or receive temporary fiscal transfers depending on their relative cyclical position vis-à-vis the eurozone average. The required size of the mutual insurance budget could be very small in practice, but still provide significant stabilizing effects (Pisani-Ferry et al. 1993). As with symmetric shocks, the stabilizing effects in case of exogenous asymmetric shocks, too, would largely work through automatic stabilizers in place at the national level. A mutual insurance scheme featuring the Euro Treasury at the center will add temporary breathing space, functioning as a fiscal clearing house and liquidity pool for any temporary mismatches arising from the automatic operation of the mutual insurance scheme.

Mutual insurance runs into trouble if endogenous asymmetric shocks are not prevented. These are shocks that result from within the policy regime itself as member states deviate from a policy course as required for convergence and cohesion. In contrast to randomly distributed exogenous shocks that can be appropriately countered without leading to permanent transfers, the endogenous variety leads to rising intra-area divergences and the buildup of imbalancesimbalances that can ultimately give rise to permanent transfers. At least until a full-fledged fiscal transfer union becomes politically acceptable, preventing the emergence of endogenous asymmetric shocks will be imperative. 
Figure 2 ECB's 2\% Stability Norm and Germany's Übercompetitiveness

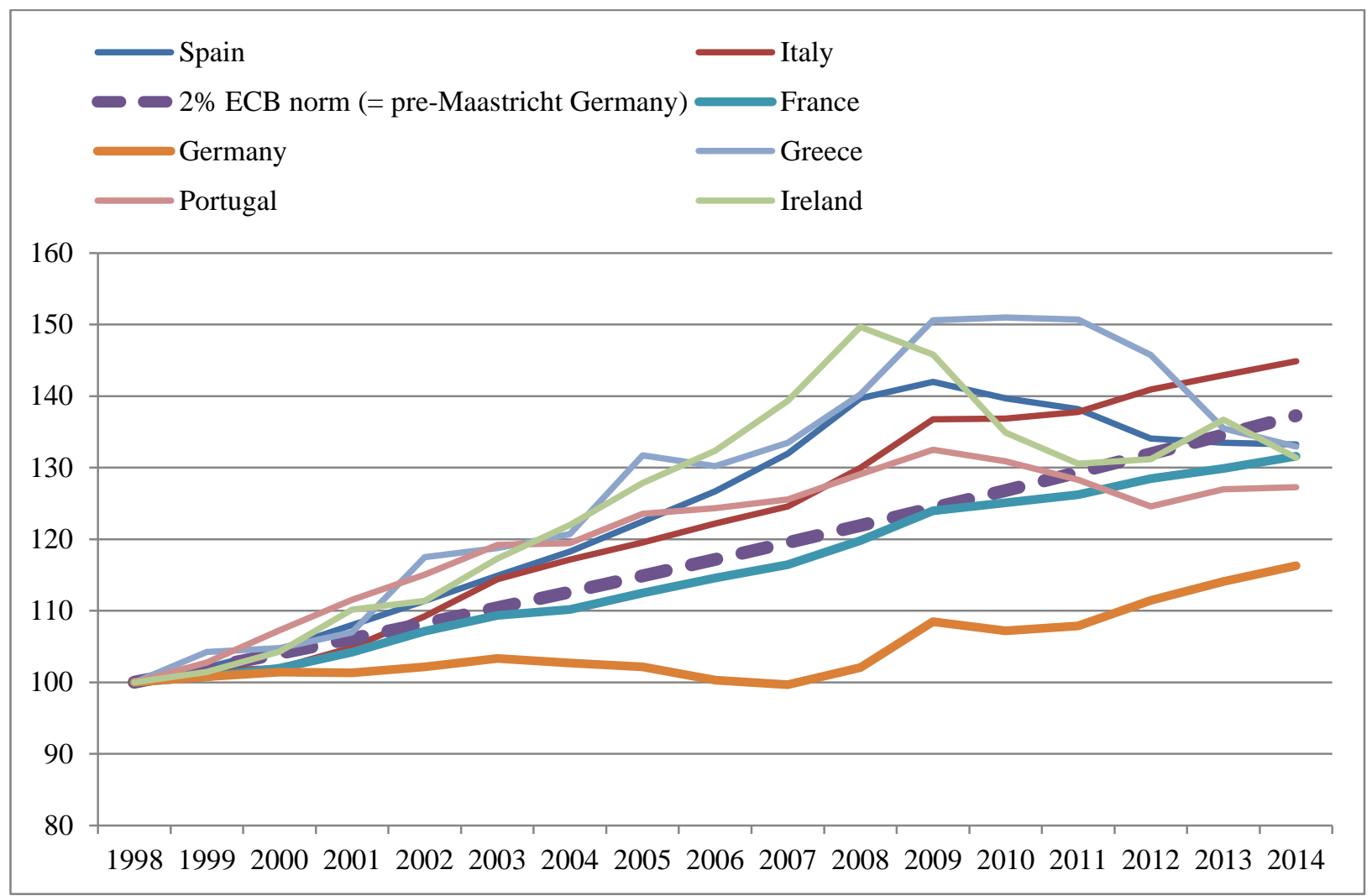

Sources: Eurostate Ameco database; own calculations.

Note: Nominal unit labor costs, total economy.

The starkest example of an endogenous asymmetric shock occurred when German wages stopped growing under the euro, so that nominal unit-labor costs stayed essentially flat for the first ten years of the euro's life (see Figure 2). This was in conflict with what may be dubbed the "golden rule of monetary union": unit-labor cost trends of member states must stay aligned with the currency union's common price stability norm (i.e. the ECB's inflation target of "below, but close to, 2 percent"); unless truly exogenous asymmetric shocks warrant any intra-area adjustment in competitiveness positions. As Germany persistently diverged from the common stability-oriented wage (and unit-labor cost) norm, member states' competitiveness positions ran out of kilter and intra-area imbalances ballooned (Bibow 2006b, 2007; Flassbeck 2007). The eventual implosion of these imbalances is at the heart of the still unresolved euro crisis, which prompted support from the ECB's balance sheet and emergency loans from shared quasi-fiscal rescue facilities (and the IMF; see Bibow 2012, 2013a).

A currency union may be able to sustain differences in income levels with minimal redistribution policies for quite some time. But maintaining balanced competitiveness positions 
is essential since failure to do so can drive weaker member states into bankruptcy fairly quickly. It is truly ironic that the euro, supposedly the culmination of Europe's post-war endeavors to ban beggar-thy-neighbor currency devaluation, saw Germany diverge from its own historical 2percent stability norm as reflected in wage and unit-labor cost trends once it had convinced its euro partners to sign up to it. The legacies of the avoidable endogenous asymmetric shock are haunting the eurozone today. Alas, Germany remains in denial of the following trilemma of its own making. Germany's "euro trilemma" is that it "cannot have it all — perpetual export surpluses, a no-transfer / no-bailout monetary union, and a "clean," independent central bank" (Bibow 2012). Germany is firmly opposed to a transfer union but insists on policies that will inevitably lead to one. Preventing permanent transfers presupposes preventing persistent divergences in competitiveness positions.

\section{THE EURO TREASURY PLAN AS A RECOVERY PROGRAM}

The Euro Treasury plan would heal the euro's potentially fatal birth defects. It creates a central fiscal institution operating side by side with the ECB. Establishing the treasury-central bank axis at the center of power of the eurozone is essential. Over time a sizeable common public debt stock will emerge while national public debt levels will shrink to low and safe levels. No debt mutualization is involved, though. Steady deficit-spending at the center to fund the public investment that is the basis of Europe's common future will allow and enable national treasuries to balance their structural current budgets (see Figure 1).

In a number of ways, the Euro Treasury will actually also provide short-term recovery support, both directly and indirectly. One direct stimulus arises from the fact that the proposed amount of public investment spending exceeds current spending. Due to counterproductive austerity measures, public investment has plunged and now stands at only 2 percent of GDP, threatening to undermine Europe's common future. A return to, say, 3 percent (as assumed in Figure 1) would thus provide an immediate and direct boost to growth of 1 percent of GDP. In view of the vastly depressed state of the eurozone economy, it may be advisable to begin with 
an even bigger initial boost for a couple of years, followed by a gradual decline to 3 percent of GDP in subsequent years. ${ }^{3}$

Another direct stimulus effect results from the fact that focusing the eurozone's fiscal regime on balancing national structural current budgets (while separating and pooling the capital budget at the center) fundamentally changes the austerity outlook overall. The required degree of further consolidation at the national level will be diminished accordingly. Fiscal space will be restored.

A related important relief and stimulus arises indirectly through declining interest rates. In principle, member states will see their tax contributions to finance the interest burden on the Euro Treasury debt gradually build up over time as their debt service on national public debt is set to decline simultaneously. Replacing a flawed regime by a functional one and gradually transitioning from servicing high-interest national debt to servicing low-interest common debt results in significant overall budgetary relief. This benefit arises rapidly as soon as national debt ratios are seen as being set on favorable trajectories and credit ratings improve. In other words, the Euro Treasury will allow for a favorable effect on sustainable national primary budgets that should be stimulatory overall.

Owing to the flawed euro regime, euro crisis countries have been laboring under highly adverse conditions. The current regime has forced them to aim for very sizeable primary budget surpluses. Belatedly, the ECB's recent QE initiative has significantly reduced interest rates and interest spreads for most members. However, given that nominal GDP growth is stuck at extraordinarily low levels today, negative in some cases, debt dynamics remain rather unfavorable for many member states. Ultimately, dynamics for the Euro Treasury debt should be similarly favorable as in the US case. Permanent primary deficits are a realistic prospect. This benefit will be gradually shared among currency union members as the transition progresses.

The recovery program that is part of the Euro Treasury plan will foster a benign rebalancing of intra-area competitiveness positions. Currently, the rebalancing process inside the euro currency union is very asymmetric: euro crisis countries are forced to undergo "internal devaluation" without any concomitant pressure on creditor countries to expand. Figure 2 shows that unit-labor costs in euro crisis countries (except for Italy) have converged back to the path

\footnotetext{
${ }^{3}$ Furthermore, the member states may be advised or even required to normally use the 0.5 -percent structural deficit allowed by the SGP for public investment.
} 
prescribed by the common stability norm as set by the ECB. Furthermore, unit-labor costs in Germany have roughly increased at an average annual two-percent rate since 2009, partly due to slightly faster rising wages and partly due to depressed levels of investment and productivity growth. The problem is that a sizeable intra-area competitiveness gap vis-à-vis Germany still remains (20 percent ballpark). Unless wage-price inflation accelerates in Germany, Germany's euro partners will be forced even deeper into internal devaluation and endure costly debt deflation processes. This grim outlook includes even France, a member state which had actually stayed very close to the stability norm all along. The implications for risks to political stability are bleak.

The Euro Treasury plan would make for a more symmetric and benign (less deflationary) rebalancing of the currency union. For instance, Germany would see a significant rise in public investment spending while the country's quite sizeable structural current budget surplus would add to the expansionary fiscal effect. This example underlines the importance of interpreting the balanced-budget rule of the SGP in a sensibly symmetric way. If members were allowed to target excessive budget surpluses, this would risk undermining intra-union balance just as much as in the opposite case. It may at first seem counterintuitive to stimulate a boom in Germany of all countries. Would it not make more sense to focus stimulus measures on the severely depressed euro crisis countries? The point is that faster domestic demand growth and higher wage-price inflation in Germany would make a vital contribution towards a more benign rebalancing and proper recovery of the eurozone as a whole. Indirectly, a benign rebalancing and stronger German domestic demand growth would also be greatly beneficial for euro crisis countries.

At the same time, normalization of credit spreads and convergence of interest rates across the currency union will also beget important relief for private borrowers, especially in euro crisis countries. The current fragmentation of financial markets within Europe's currency union defeats the whole purpose of both the currency union and the common market. Companies in euro crisis countries are put at a lasting competitive disadvantage in financial markets solely as a result of a dysfunctional currency regime. The ECB's recent QE initiative is working in the right direction by reducing funding costs, but monetary policy action alone will not overcome existing systemic defects and resolve the crisis. A Euro Treasury partner is needed. With the Euro Treasury added to the euro regime, the term structure on Euro Treasury debt will become the common benchmark for financial instruments issued by debtors of euro 
member states irrespective of nationality. As a level financial playing field gets established, the promise of the common market and common currency will finally be fulfilled.

\section{SUMMARY: THE EURO TREASURY MAKES THE EURO VIABLE}

The euro crisis remains unresolved and the euro currency union incomplete and extraordinarily vulnerable.

The Euro Treasury plan proposed here amounts to a rudimentary fiscal union, not a transfer union, though, as benefits and contributions are shared proportionately. The Euro Treasury would allocate investment grants to member states based on their GDP shares. And it would collect taxes to service the interest on the common debt, also exactly in line with member states' GDP shares. In the first instance, this would safeguard and steady public investment spending across the eurozone. There would be no mutualization of existing national debts, though. The plan is purely forward-looking. Following the "golden rule of public finance," the Euro Treasury would issue common Euro Treasury bonds to fund the joint infrastructure spending, which is the basis for the union's joint future.

Member states would still be required to abide by all the rules of the current euro regime, but this would apply to current public expenditures only - as national public capital expenditures would form a separate capital budget funded through common euro treasury bonds. The Euro Treasury plan thereby enables the decline in national public debt ratios to low and safe levels, restoring the fiscal space for automatic stabilizers to operate freely at the national level. The ECB needs Euro Treasury debt for monetary policy purposes. And the markets need Euro Treasury debt for establishing a common benchmark for financial instruments issued by debtors of euro member states, irrespective of nationality. The Euro Treasury would establish the vital treasury-central bank axis of power. It would not only heal the euro's potentially fatal birth defects but also provide the needed stimulus to end the crisis. The original euro experiment has failed. It is high time to relaunch the euro on a sounder footing.

As a recovery program, the Euro Treasury plan offers an attractive transition from the current crisis mode toward a more prosperous trajectory. The plan foresees an immediate boost to public investment spending across the eurozone. Moreover, the switch to applying the SGP (cum Fiscal Compact) to national current spending (exclusive of capital spending funded at the center) and the prospective decline in the interest burden will open up further fiscal space. The 
resulting area-wide fiscal stimulus will allow a more benign (less deflationary) intra-area rebalancing to unfold.

It could be argued that the Euro Treasury plan amounts to relaunching the euro on a sounder footing while leaving unaddressed the debt overhangs, which are a legacy of Europe's failed currency union experiment. A fiscal union that is specifically designed not to be a transfer union cannot directly address this issue. However, by switching from a public thrift campaign that can only impoverish Europe to a public investment campaign designed to secure Europe's future, the Euro Treasury scheme will reignite growth and thereby establish more favorable debt dynamics across the union. GDP growth through public deficit spending at the center will also greatly improve the situation of banks across the union even without more direct capital support. Hopefully, improved overall performance under the new euro regime proposed here will lead to more solidarity and forgiveness of blunders of joint responsibility over time. The EU budget provides a potential avenue for redistribution policies addressing the division between creditor and debtor nations that has come to afflict Europe's currency union. Acknowledging that fullfledged political union may be a long way off and German fears of a "transfer union" difficult to appease, the Euro Treasury plan more narrowly focuses on what may be feasible in the near future. Arguably, the Euro Treasury plan would both stimulate a broad-based recovery and prepare for ground for further integration in the future. 


\section{References}

Avgouleas, A. and Goodhart, C.A.E. (2014) "A Critical Evaluation of Bail-in as a Bank Recapitalization Mechanism.” International Macroeconomics Discussion Paper Series no. 10065, London, CEPR.

Ball, L. (1997) "Disinflation and the NAIRU." In C.D. Romer and D.H. Romer, eds. Reducing Inflation: Motivation and Strategy, University of Chicago Press: 176-94.

BCBS (2011) "Basel III: A Global Regulatory Framework for More Resilient Banks and Banking Systems, BIS, Basel, http://www.bis.org/publ/bcbs189.pdf

Bibow, J. (2001) "Making EMU Work: Some Lessons from the 1990s." International Review of Applied Economics 15(3): 233-59.

(2006a) "Inflation Persistence and Tax-push Inflation in Germany and the Euro Area: A Symptom of Macroeconomic Policy Mismanagement?” IMK Study, 1/2006.

(2006b) "The Euro Area Drifting Apart - Does Reform of Labor Markets Deliver Competitive Stability or Competitive Divergence?" in Structural Reforms and MacroEconomic Policy, ETUC: 76-86.

(2007) "How the Maastricht regime Fosters Divergence as Well as Instability." In P. Arestis, E. Hein, and E. Le Heron, eds. Monetary Policies - Modern Approaches, Basingstoke and New York: Palgrave Macmillan:197-222.

(2012) “The Euroland Crisis and Germany's Euro Trilemma, International Review of Applied Economics 27(3): 360-85.

(2013a) “Germany and the Euroland Crisis: The Making of a Vulnerable Haven.” Levy Economics Institute Working Paper No. 767, June. http://www.levyinstitute.org/publications/?docid=1833

(2013b) "Lost at Sea: The Euro Needs a Euro Treasury." IMK, Düsseldorf, November, http://www.boeckler.de/pdf/p_imk_study_35_2013

Blanchard, O. and Giavazzi, F. (2004) "Improving the SGP through a Proper Accounting of Public Investment.” CEPR Discussion Paper No. 4220.

Blanchard, O. and Leigh, D. (2013) “Growth Forecast Errors and Fiscal Multipliers.” IMF working paper $13 / 1$.

Claessens, S., Mody, A., and Vallee, S. (2012) Paths to Eurobonds, IMF Working Paper 12/172, July.

Darvas, Z., Pisani-Ferry, J. and Wolff, G. (2013) "Europe's Growth Problem (and What to Do about It)." Bruegel, April 12. http://www.bruegel.org/publications/publicationdetail/publication/776-europes-growth-problem-and-what-to-do-about-it/ 
DeLong, J.B. and Summers, L.H. (2012) "Fiscal Policy in a Depressed Economy." Brookings Papers on Economic Activity, Spring, 233-97.

Delpla, J. and von Weizsäcker, J. (2010) “The Blue Bond Proposal.” Bruegel Policy Brief, 2010/3, Brussels: Bruegel.

Deutsche Bundesbank (2012) "Die Schuldenbremse in Deutschland - Wesentliche Inhalte und deren Umsetzung." Monatsbericht Oktober, Frankfurt a. Main, 15-40.

Deutscher Gewerkschaftsbund (2012) “A Marshall Plan for Europe.” Proposal by the DGB for an economic stimulus, investment and development programme for Europe, December.

ECLM/IMK/OFCE (2014). Independent Annual Growth Survey 2015, third report, Brussels, December.

European Council (2012). Towards a Genuine Economic and Monetary Union, Report by the President of the European Council, in collaboration with the Presidents of the Commission, the Eurogroup and the ECB, December 5.

http://www.consilium.europa.eu/uedocs/cms_Data/docs/pressdata/en/ec/134069.pdf

Eyraud, L. and Weber, A. (2013). "The Challenge of Debt Reduction during Fiscal Consolidation." IMF working papers 13/67.

Flassbeck, H. (2007) "Wage Divergences in Euroland: Explosive in the Making." In J. Bibow and A. Terzi, eds. Euroland and the World Economy - Global Player or Global Drag?, Basingstoke and New York: Palgrave Macmillan.

Godley, W. (1992) "Maastricht and All that: Letter from Europe." London Review of Books, 14(19): 3-4.

Goodhart, C.A.E. (1992) "National Fiscal Policy within EMU: The Fiscal Implications of Maastricht." In C.A.E. Goodhart, ed. EMU and ESCB after Maastricht, London, Financial Markets Group, LSE, chapter 2.3.

(1998) "The Two Concepts of Money: Implications for the Analysis of Optimal Currency Areas." European Journal of Political Economy, 14: 407-32.

(2007) "Replacing the Stability and Growth Pact?" In J. Bibow and A. Terzi, eds. Euroland and the World Economy: Global Player or Global Drag? Basingstoke and New York: Palgrave Macmillan, 135-53.

Goodhart, C.A.E. and Smith, S. (1993) "Stabilization." In "The Economics of Community Public Finance.” European Economy, 5(V): 493-510.

Hein, E. and Truger, A. (2007) "Fiscal Policy and Macroeconomic Performance in the Euro Area: Lessons for the Future." In J. Bibow and A. Terzi, eds. Euroland and the World Economy: Global Player or Global Drag? Basingstoke and New York: Palgrave Macmillan. 
Hellwig, C. and Philippon, T. (2011) "Eurobills, not Eurobonds." VoxEU, December 2, http://www.voxeu.org/article/eurobills-not-euro-bonds

Howarth, D. and Quaglia, L (2013) "Banking on Stability: The Political Economy of New Capital Requirements in the European Union." Journal of European Integration, 35(3): 333-46.

Mundell, R.A. (1961) “A Theory of Optimum Currency Areas.” American Economic Review 53: 657-65.

Musgrave, R.A. (1939) "The Nature of Budgetary Balance and the Case for a Capital-budget." American Economic Review, 29: 260-71.

Musgrave, R.A. (1959).The Theory of Public Finance. A Study in Public Economy, New York: McGraw-Hill.

Perotti, R. (2013) “The ‘Austerity Myth’: Gain without pain?” NBER No. 17571.

Pisani-Ferry, J., Italianer, A. and Lescure, R. (1993) "Stabilization Properties of Budgetary Systems: A Simulation Analysis.” European Economy, 5: 513-38.

Tommaso Padoa-Schioppa Group (2012). Completing the Euro: A Road Map Towards Fiscal Union in Europe, Notre Europe, June 26.

Ubide, A. (2013) "How to Form a More Perfect European Banking Union.” Policy Brief: 13-23, Peterson Institute for International Economics, October.

Varoufakis, Y., Holland, S., and Galbraith, J.K. (2013) "A Modest Proposal for Resolving the Eurozone Crisis, Version 4.0.” July. 